\title{
Direct observations of groups of mysids in shallow coastal waters of western Japan and southern Korea
}

\author{
S. Ohtsuka ${ }^{1}$, H. Inagaki ${ }^{2}$, T. Onbe ${ }^{2}$, K. Gushima ${ }^{2}$, Y. H. Yoon ${ }^{3}$ \\ ' Fisheries Laboratory, Hiroshima University, Takehara, Hiroshima 725, Japan \\ ${ }^{2}$ Faculty of Applied Biological Sciences, Hiroshima University, Higashi-Hiroshima 739, Japan \\ ${ }^{3}$ Department of Oceanography, Yosu National Fisheries University, Yosu 550-749, Korea
}

\begin{abstract}
Groups (swarms, schools or aggregations) of mysids occurring in shallow coastal waters of western Japan and southern Korea were directly observed by SCUBA and skin divers during the day. Formation of groups was seen in 16 species belonging to the family Mysidae. These groups were often polyspecific, composed of 1 dominant species accounting for 50 to $100 \%$ of the number of individuals in the group and 0 to 5 guest species. Nipponomysis spp., Prionomysis aspera and Tenagomysis sp. formed flat, carpet-like or discoid swarms over sandy bottoms. Anisomysis aikawai, A. ijimai, A. mixta, A. pelewensis, Anisomysis spp., Lycomysis bispina, Nipponomysis sp., Paracanthomysis hispida, Siriella sp., and an unidentified leptomysid aggregated in shapes of ovals, spheres and columns $L$. bispina and $P$. hispida were associated with algal beds. Other swarms were located near isolated rocks over sandy bottoms, near the edges of corals or along the seashore. Swarms were classified into 2 types in terms of mobility: stationary and migratory; however, the mobility of the swarms was changeable with season and with sexual maturity. Most swarms were made up of various developmental stages, but some swarms of $A$. aikawai and $A$. ijimai consisted only of juveniles. Densities of mysids in a swarm ranged from 13 to 571 ind. $1^{-1}$ Sex ratios $\left(0^{*} / 0\right)$ of immature and mature males and females within a group varied between 0.22 and 2.40. Possible adaptive values of mysid groupings are discussed on the basis of present and previous findings: (1) antipredation. (2) maintenance of favorable position, and (3) feeding.
\end{abstract}

KEY WORDS: Mysid - Swarm · School Aggregation - Group

\section{INTRODUCTION}

Zooplankters such as copepods, mysids and euphausiids have been observed to actively form swarms and schools (e.g. Clutter 1969, Mauchline 1971, Wittmann 1977, Hamner \& Carleton 1979, Omori \& Hamner 1982, Ueda et al. 1983, Tanimura et al. 1984, Kimoto et al. 1988, O'Brien 1988a, b, Inagaki 1990). Various adaptive functions have been postulated by these authors to explain the active grouping of these zooplankters, i.e. maintaining a position within a favorable habitat, reducing dispersal by currents, enhancing antipredation, facilitation of breeding, and contributing to population regulation. In particular, the first 4 functions have been suggested to be most important (Clutter 1969, Hamner \& Carleton 1979, Omori \&
Hamner 1982, O'Brien 1988b). On the other hand, it was suggested by Tanaka et al. (1987a, b) that copepod swarms may provide a favorable food source for juvenile fishes.

Gregarious behaviors of mysids have so far been investigated both in the field and laboratory (e.g. Steven 1961, Emery 1968, Clutter 1969, Zelickman 1974 Wittmann 1977, Omori \& Hamner 1982, Kakimoto et al. 1983. Morioka \& Kimoto 1986, O'Brien et al. 1986, O'Brien 1988b, O'Brien \& Ritz 1988). However, direct observations on mysid groups have never been made in detail in Japanese and Korean waters, although mysids are one of the most important food items for juveniles of coastal fishes such as halibut and sea bream (e.g. Imabayashi 1980, Kiso 1980, 1981). The present paper deals with the characteristic properties, 
such as shapes, behaviors, substrate association, densities, species and stage compositions, and sex ratios, of mysid groups occurring in the shallow waters of western Japan and southern Korea and discusses the present results in comparison with previous findings.

\section{MATERIALS AND METHODS}

Several terms such as swarm, school, shoal and cluster have been introduced to describe the morphology of mysid groups (Clutter 1969, Mauchline 1971, Wittmann 1977, O'Brien 1988b). According to O'Brien (1988b), active, integrated aggregations of mysids can be 'facultative' and 'obligate'; the former is caused by both intrinsic and extrinsic factors and the latter only by internal biological mechanisms. However, it is difficult to distinguish the latter from the former in situ. Therefore, the terms swarms, schools and aggregations as defined by Wittmann (1977) are used in the present paper:

Swarm: close group showing regularity in spatial arrangement; staying in the same position.

School: swarms consisting of individuals swimming in the same direction; either staying in the same position or migrating actively.

Aggregation: no or reduced regularity in spatial arrangement; large groups made up of smaller groups of swarms and/or schools.

Group: swarms, schools and aggregations.

Direct observations of mysid groups were made by skin and/or SCUBA divers at 19 stations in shallow coastal waters of western Japan and southern Korea (Fig. 1, Table 1). All groups were observed during the day. Sampling dates and gregarious species observed are listed in Table 1. A dominant species is defined here as a species comprising $>50 \%$ of individuals in a group. Before sampling a mysid group, the following biological and physical characters were recorded using an underwater notebook: (1) shape, dimension and movement of the group; (2) behavior and orientation of individuals within the group (3) body color of individuals; (4) water current and direction; (5) topography and position of the group. In some cases an underwater camera (Nikon, Nikonos $\mathrm{V}$ with an $80 \mathrm{~mm}$ macro lens and a close-up lens) or an underwater VTR (Victor, BR-S20, UV-B33) was employed to record the movement of the groups. After observation, each group was rapidly swept several times with a hand net $(30 \mathrm{~cm}$ diameter, $80 \mathrm{~cm}$ length, $224 \mu \mathrm{m}$ mesh size) which was closed with a diver-operated closing system soon after collection. Mysids were preserved with $10 \%$ neutralized sucrose-formalin
(Toda \& Takahashi 1982). Group dimensions were measured with a plastic scale for small-sized swarms or schools and approximated with divers' body lengths for large groups. If the net swept all individuals in a group, then that group could be regarded as a rectangular prism, sphere or column and density was estimated. A nearest-neighbor distance (NND, distance between 2 nearest neighbors; Partridge 1980) in a swarm was calculated from its numerical density.

In several instances only part of a group was sampled (see Tables 1, $3 \& 4$ ); e.g. Anisomysis aikawai, a large school $(15 \times 10 \times 200 \mathrm{~cm})$ at Stn 13, 27 Sep 1988 ; A. ijimai, a small school ( $15 \mathrm{~cm}$ in diameter) at Stn 2, 13 Oct 1987, a large school $(200 \times 50 \times 200 \mathrm{~cm})$ at Stn 4,5 Aug 1988, 2 large schools $(30 \times 30 \times 200$ and $40 \times 40 \times$ $400 \mathrm{~cm}$ ) at Stn 7, 7 Jan 1989; Anisomysis sp. 1, a large swarm $(30 \times 30 \times 200 \mathrm{~cm})$ at $\operatorname{Stn} 16,22$ May 1989; Paracanthomysis hispida, a school $(30 \times 20 \times 20 \mathrm{~cm})$ at Stn 6 , 6 May 1989; Prionomysis aspera, a swarm $(20 \times 5 \times 5 \mathrm{~cm})$ at Stn 9, 20 Mar 1989; Tenagomysis sp., a swarm (30× $25 \times 10 \mathrm{~cm}$ ) at Stn 13,27 Sep 1988, an aggregation at Stn 13, 15 May 1989 (a huge aggregation along sea bottom at substrate distance of 0 to $50 \mathrm{~cm}$ ).

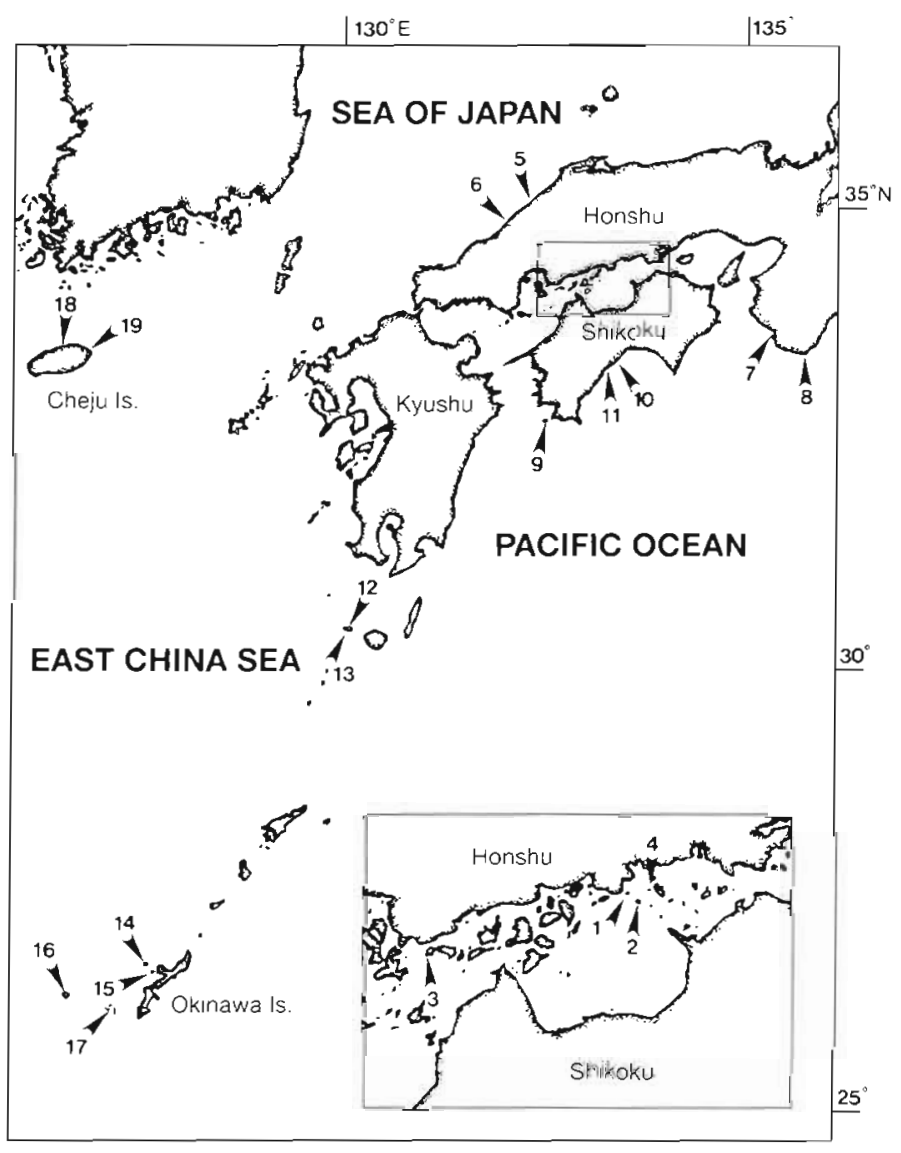

Fig. 1 Observation stations off western Japan and Cheju Island, Korea. Sampling dates and topography shown in. Table 1 
Table 1 Sampling stations, localities, bottom topographies, dates and dominant species of swarming/schooling mysids

\begin{tabular}{|c|c|c|c|c|}
\hline Stn & Locality & $\begin{array}{l}\text { Bottom topography } \\
\text { (Group formation depth: m) }\end{array}$ & Date & $\begin{array}{l}\text { Dominant species } \\
\text { (No. of samples examined) }\end{array}$ \\
\hline \multicolumn{5}{|c|}{ Seto Inland Sea, Japan } \\
\hline 1 & Sensui Island & Sandy bottom, brown algae $(2-6)$ & $\begin{array}{l}2 \text { Feb } 1988- \\
14 \text { Jun } 1989\end{array}$ & $\begin{array}{l}\text { Lycomysis bispina (25), } \\
\text { Anisomysis ijimai (1) }\end{array}$ \\
\hline 2 & Hashiri Island & Sandy bottom (4) & 13 Oct 1987 & Anisomysis ijimai $(1)$ \\
\hline 3 & Shimokamagri Island & Sandy bottom, Sargassum spp beds (4) & 26 Apr 1988 & Lycomysus bispina (3) \\
\hline 4 & Kajiko Island & Sandy bottom (6) & 5 Aug 1988 & Anisomysis ijimai (1) \\
\hline \multicolumn{5}{|c|}{ Sea of Japan, Japan } \\
\hline 5 & Yunotsu & Sandy bottom $(3.5-6.5)$ & 14 Aug 1988 & Nipponomysis sp. 2(2) \\
\hline 6 & Hamada & Sandy bottom, Sargassum spp. beds $(3-4)$ & $\begin{array}{l}6 \text { May } 1989 \\
17 \text { Jun } 1989\end{array}$ & $\begin{array}{l}\text { Nipponomysis sp. } 3 \text { (1), } \\
\text { Paracanthomysis hispida (2) }\end{array}$ \\
\hline \multicolumn{5}{|c|}{ Pacific coast, Japan } \\
\hline 7 & Shirahama & Sandy bottom (3-4) & $\begin{array}{l}21 \text { Nov } 1988 \\
7,8 \text { Jan } 1989\end{array}$ & $\begin{array}{l}\text { Anisomysis aikawai (1), } \\
\text { A. ijimai (3) }\end{array}$ \\
\hline 8 & Kushimoto & & 25 Feb 1989 & Anisomysis mixta (1) \\
\hline 9 & Okino Island & Sandy bottom $(3-7)$ & $\begin{array}{l}8 \text { Dec } 1987 \\
8 \text { Mar } 1988 \\
20 \text { Mar } 1989\end{array}$ & $\begin{array}{l}\text { Anisomysis ijimai (2), } \\
\text { Nipponomysis sp. (1), } \\
\text { Prionomysis aspera (1) }\end{array}$ \\
\hline 10 & Kutsu & Sandy bottom, brown algae $(1-10)$ & 7 Jun 1988 & $\begin{array}{l}\text { Anisomysis mixta (3), } \\
\text { A. pelewensis (1) }\end{array}$ \\
\hline 11 & Suzaki & Sandy bottom, brown algae $\{3-4\}$ & 8 Jun 1988 & Anisomysis pelewensis ( 3 ) \\
\hline \multicolumn{5}{|c|}{ Kuchinoerabu Island, Japan } \\
\hline 12 & Nishiura Bay & Sandy and gravelly bottoms $(2-6)$ & 22, 29 Sep 1988 & $\begin{array}{l}\text { Anisomysis mixta }(1) \\
\text { A. pelewensis }(1) \\
\text { Anisomysis sp. } 2(1)\end{array}$ \\
\hline 13 & Honmura Bay & Sandy and gravelly bottoms $(2-5)$ & $\begin{array}{l}27 \text { Sep } 1988 \\
3 \text { Oct } 1988 \\
\text { 14-16 May } 1989\end{array}$ & $\begin{array}{l}\text { Anisomysis aikawai (3), } \\
\text { A. mixta (1), } \\
\text { Nipponomysis sp. } 1(1) \text {, } \\
\text { Siriella sp. (1), Tenago- } \\
\text { mysis sp. (2), unidentified } \\
\text { Leptomysini (1) }\end{array}$ \\
\hline \multicolumn{5}{|c|}{ Ryukyu Islands, Japan. } \\
\hline 15 & Sesoko lsland & Sandy bottom, corals (6) & 12 May 1988 & Anisomysis aikawai (1) \\
\hline 16 & Kume Island & Sandy bottom, corals (1) & 22 May 1989 & Anisomysis sp. $1(2)$ \\
\hline 17 & Kerama Islands & Sandy bottom $(<1)$ & 21 May 1989 & Anisomysis sp. $3(1)$ \\
\hline \multicolumn{5}{|c|}{ Cheju Island, Korea } \\
\hline & Itokuri & Sargassum spp. beds (4) & 30 Aug 1989 & Paracanthomysis hispida (1) \\
\hline 19 & Songsan & Sandy bottom, Sargassum spp. beds $(2-7)$ & 1 Sep 1989 & $\begin{array}{l}\text { Anisomysis ijimai (1), } \\
\text { Paracanthomysis hispida (2) }\end{array}$ \\
\hline
\end{tabular}

Mysid swarms were classified into 2 types on the basis of their social behavior: stationary and migratory. The stationary type was characterized by maintenance of the whole group at almost the same location, at least throughout the observation time. The migratory type was characterized by active, mainly horizontal, migration in which all individuals were swimming in the same direction. This behavior can be referred to as migratory schooling and differs from the 'escape response' (O'Brien \& Ritz 1988).

The body lengths of Anisomysis ijmai collected at Stns 7 and 9 were measured from the base of the eyestalk to the terminal end of the sixth abdominal somite (Morioka \& Kimoto 1986). Only non-damaged and straight specimens taken from the samples were measured
A swarm of Anisomysis mixta at Stn 8 was collected by $\mathrm{Mr} \mathrm{K}$. Nomura (Sabiura Marine Park Research Station) and kindly provided to us. Anisomysis sp. 1 and Anisomysis sp. 3 are undescribed species, and Anisomysis sp. 2 is very similar to $A$. maris rubri (M. Murano pers. comm.).

\section{RESULTS}

\section{Species composition}

During the present investigation, 16 dominant species belonging to the family Mysidae were found to form groups (Table 1). Some groups were made up of a single species, and others were composed of 1 domi- 
nant species, which made up more than $50 \%$ of a group, and 2 to 5 'guest' (Wittmann 1977) species. Anisomysis aikawai, A. ijmmai, A. mixta, A. pelewensis, Paracanthomysis hispida, Lycomysis bispina, Prionomysis aspera, Anisomysis sp. 1 and Anisomysis sp. 2 formed monospecific groups. The first 6 species were often accompanied by guest species. Except for Doxomysis sp. and Parastylomysis secunda, which were not observed forming groups in the present study, almost all the guest species had the capability of becoming the dominant species in a group. The interrelationships between dominant and guest species found in the present investigation are summarized in Fig. 2.

Guest species usually comprised less than one-tenth of the number of individuals within a group (Table 3). In Anisomysis aikawai and Lycomysis bispina, however, guest species comprised approximately half of the constituents. In the case of A. aikaiwai (Stn 15, 12 May 1988), 2 guest species, A. pelewensis and Doxomysis sp., accounted for 36 and $14 \%$, respectively. A swarm of $L$. bispina collected at Stn 1 on 11 June 1988 contained Nipponomysis fusca guests comprising $48 \%$ of the swarm.

\section{Social behavioral types of swarms}

Individuals in the groups were either 'polarized' (uniformly oriented) or 'unpolarized' (randomly ori- ented) (O'Brien 1988b) (Table 2). All swarms with unpolarized constituents and some schools were found stationary at the same locations. Polarization in stationary groups seemed to be caused only by physical factors such as water currents and proximity of substratum: constituents quickly changed their orientation in response to current, and they continued swimming near discontinuities such as rocks and algae. Stationary swarms of Anisomysis mixta, Lycomysis bispina, Nipponomysis sp. 2, Nipponomysis sp. 3, Siriella sp. and an unidentified leptomysid consisted of polarized constituents. Among them, A. mixta, Nipponomysis sp. 2 and Nipponomysis sp. 3 were observed quickly changing their orientation in response to strong waves.

Categories of social behaviors of the mysids sampled are shown in Table 2. Lycomysis bispina formed stationary swarms throughout the year, regardless of developmental stages of individuals; however, constituents were both polarized and unpolarized. Anjsomysis mixta formed only stationary swarms irrespective of locality and developmental stages, whereas A. pelewensis formed only migratory schools. Schools of Paracanthomysis hispida actively migrated only around and within Sargassum spp. beds and sometimes stopped migrating when they entered the vicinity of algae (see Fig. 5C).

The social behavioral types of mysids were changeable in some species. Tenagomysis sp. formed different types of groups in September 1988 and May 1989: in

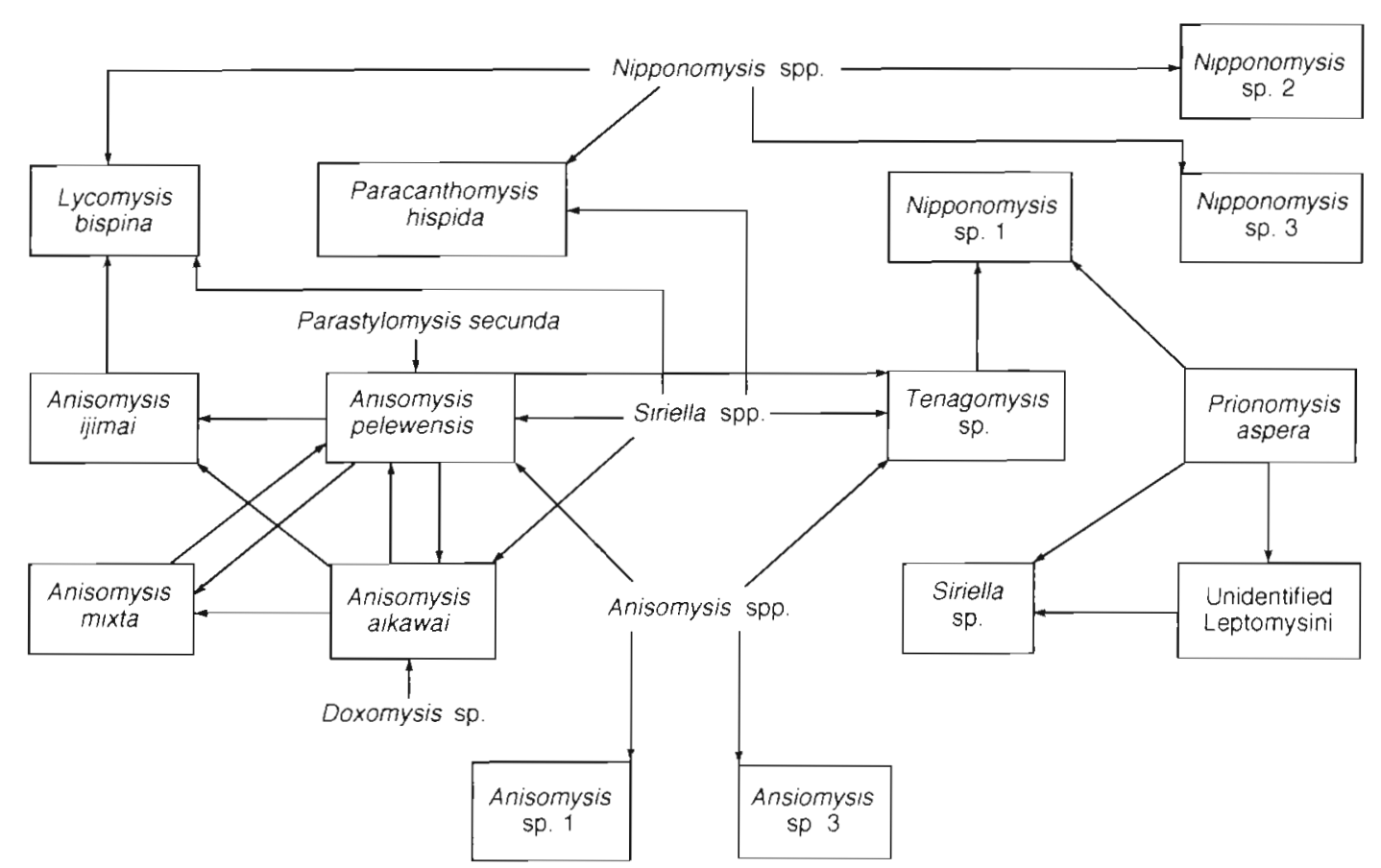

Fig. 2. Relationships between dominant and guest species of mysids 
Table 2. Social behavioral types of mysid swarms and schools

\begin{tabular}{|c|c|}
\hline Type & Species \\
\hline $\begin{array}{l}\text { Stationary } \\
\text { (individuals } \\
\text { unpolarized) }\end{array}$ & $\begin{array}{l}\text { Anisomysis aikawai (Stn 13; } \\
\text { juveniles dominant), Anisomysis } \\
\text { ijimai (Stns } 9 \text { and } 19 \text {; juveniles dominant), } \\
\text { Anisomysis sp. } 1 \text {, Anisomysis sp. } 3 \\
\text { (swarms in aggregation), Lycomysis } \\
\text { bispina (Stns } 1 \text { and } 3 \text { ), Nipponomysis sp. } 1 \text {, } \\
\text { Prionomysis aspera }\end{array}$ \\
\hline $\begin{array}{l}\text { Stationary } \\
\text { (individuals } \\
\text { polarized) }\end{array}$ & $\begin{array}{l}\text { Anisomysis aikawai (Stn 13), A. mixta, } \\
\text { Anisomysis sp. } 3 \text { (schools in aggregation), } \\
\text { Lycomysis bispina (Stn 1), Nippono- } \\
\text { mysis sp. 2, Nipponomysis sp. 3, } \\
\text { Siriella sp., unidentified Leptomysini }\end{array}$ \\
\hline $\begin{array}{l}\text { Stationary } \\
\text { (polarization } \\
\text { not determined) }\end{array}$ & $\begin{array}{l}\text { Anisomysis aikawai (Stns } 7 \text { and } 13 \text { ), } \\
\text { Anisomysis ijumai (Stns } 2,7 \text { and } 9 \text { ), } \\
\text { Tenagomysis sp. (September) }\end{array}$ \\
\hline $\begin{array}{l}\text { Migratory } \\
\text { (individuals } \\
\text { polarized) }\end{array}$ & $\begin{array}{l}\text { Anisomysis aikawai (Stns } 13 \text { and } 15 ; \\
\text { immature/mature inds. dominant), A. } \\
\text { ijimai (Stns } 1,4 \text { and } 7, \text { immature/mature } \\
\text { inds. dominant), A pelewensis, Anisomysis } \\
\text { sp. } 2, \text { Paracanthomysis hispida, Tenago- } \\
\text { mysis sp. (May, schools in aggregationj }\end{array}$ \\
\hline
\end{tabular}

September a small, carpet-like swarm (ca $10 \mathrm{~cm}$ in thickness) was observed over a shallow hollow on the sandy bottom, in May a huge aggregation (ca $50 \mathrm{~cm}$ in thickness), which contained a number of small, actively migrating schools, was formed over the sandy bottom. Anisomysis ijimai appeared to change behavioral type with advancing developmental stages: as juveniles they formed stationary swarms, whereas migratory schools were composed more of advanced stages than of juveniles (Fig. 3).

\section{Group shape and size, substrate association, density and NND}

A schematic illustration of groups of mysids and their relationships to bottom topography as observed in the present study is depicted in Fig. 4. The shape, size, formation site and numerical density of the entire group are summarized in Table 3 .

Shapes of swarms and schools in relation to substrates are classified into 2 major types: (1) a flattened, carpet-shaped type formed exclusively just above sandy bottoms, and (2) an ovoid, spherical or column-shaped type formed at a variety of sites. Swarms of Nipponomysis sp. 1, Nipponomysis sp. 2, Pri- onomysis aspera, and Tenagomysis sp. (27 September 1988) belonged to the former type (ca 5 to $10 \mathrm{~cm}$ thick). These flattened swarms were often found over shallow hollows on the sandy bottom (Nipponomysis sp. 1 , Tenagomysis sp.), above the sand channels among rocks (Nipponomysis sp. 2) or near sand-rock boundaries ( $P$. aspera). In Nipponomysis sp. 1, a swarm was formed at a height of up to $5 \mathrm{~cm}$ above the bottom. A swarm of Tenagomysis sp. was also observed at the same hollow for $2 \mathrm{~d}$ (Stn 13, 27 to 28 Sep 1988). On 15 May 1989 Tenagomysis sp. formed a huge aggregation (about $50 \mathrm{~cm}$ thick) just above the bottom instead of a small, flat swarm over the sandy bottom at the same locality. Approximate dimensions of these flat swarms ranged from $20 \times 5 \times 5$ to $30 \times 25 \times 10 \mathrm{~cm}$. Density of swarms of Nipponomysis spp. varied from 16 to 65 ind. $1^{-1}$.

All species other than the above 4 formed ovoid, spherical or column-like swarms of various sizes located at a wide variety of sites. In Anisomysis aikawai, oval- and ball-shaped swarms were found on the lee side of rocks, corals, and the lower side of the brown alga Eckloniopsis radicosa (Fig. 5A). The shapes and sizes of the swarms varied from a small sphere of $10 \mathrm{~cm}$ in diameter to a large oval of $200 \mathrm{~cm}$ along the long axis. Density of swarms of $A$. aikawai ranged from 17 to $99 \mathrm{ind} . \mathrm{l}^{-1}$.

Ovoid and ball-shaped swarms or schools of Anisomysis ijimai (Fig. 5B) were found over sandy bottoms, with sizes ranging from a ball of $20 \mathrm{~cm}$ in diameter to a huge oval of $400 \mathrm{~cm}$ along the long axis. Density ranged from 13 to 571 ind. $\mathrm{I}^{-1}$. The maximum densities

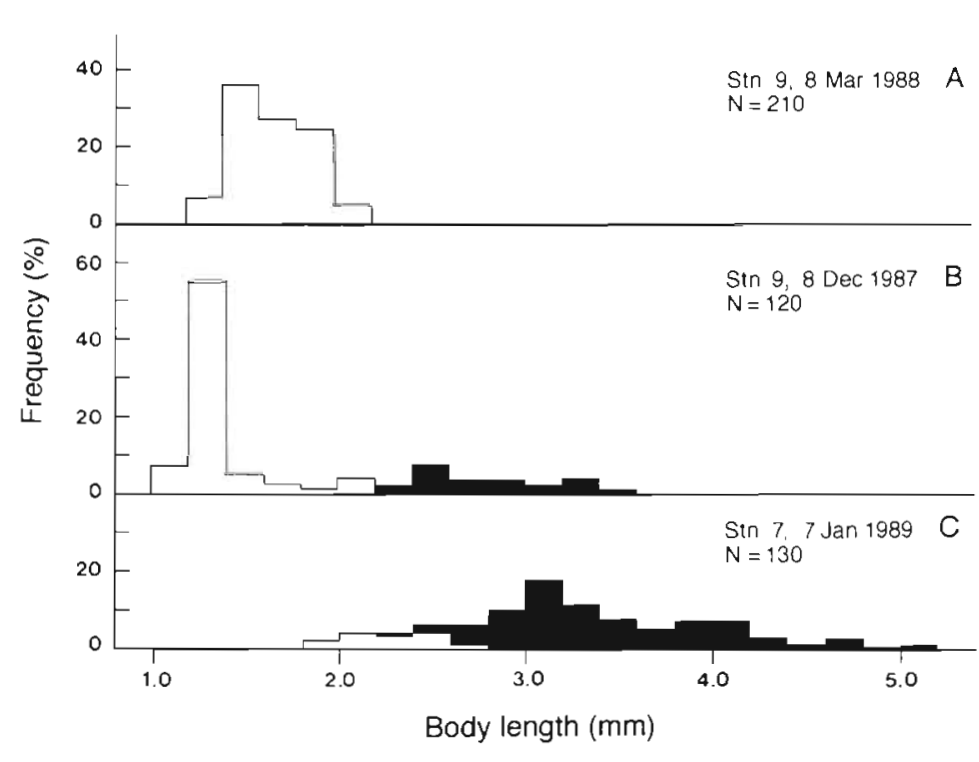

Fig. 3. Frequency distribution of body length of Anisomysis ijimai in relation to type of social behavior. (A, B) Stationary type swarms; (C) migratory type school. ( $\square$ ) Juvenile; ( $\square$ ) female and male 

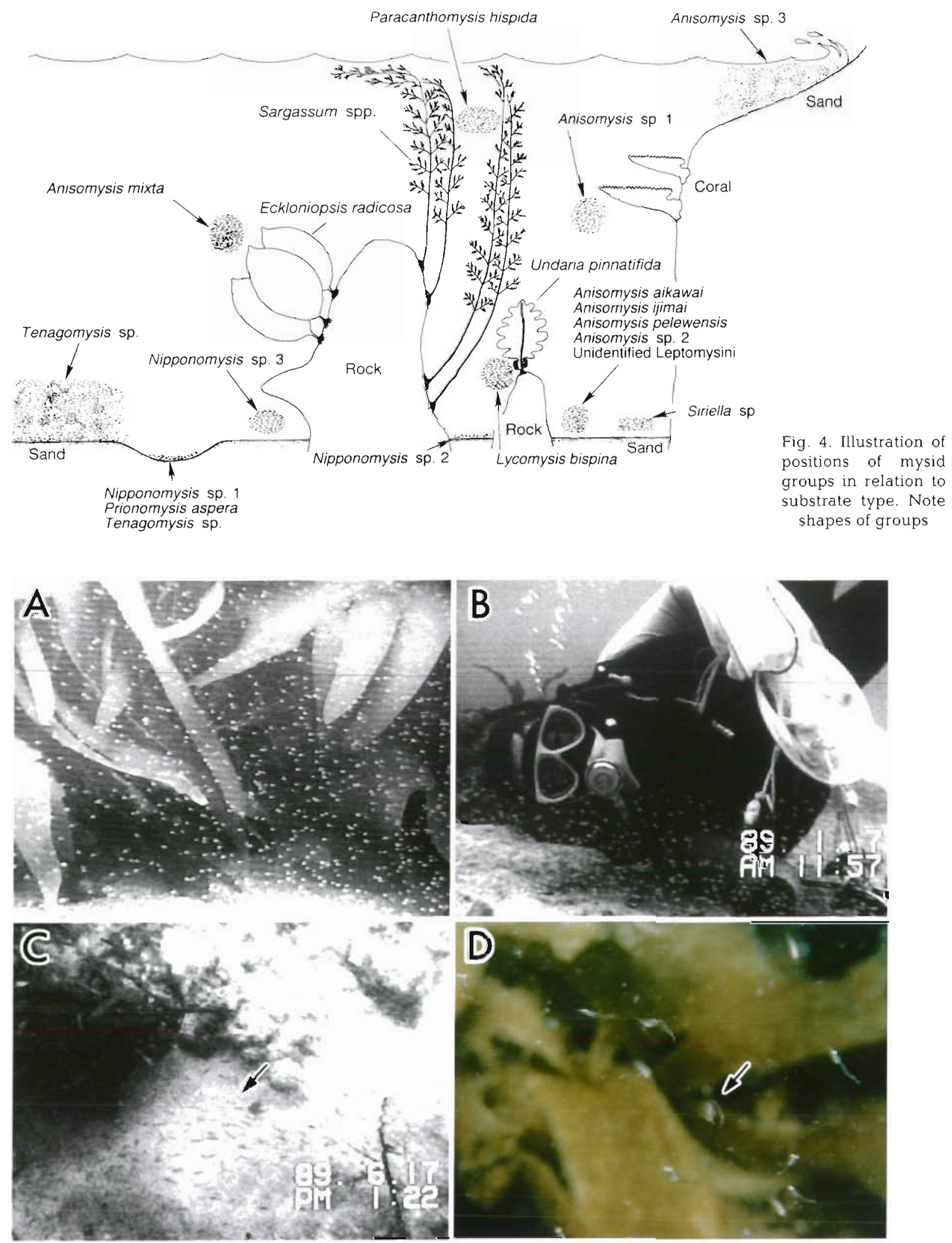

Fig. 5. Mysid swarms/schools observed in the field (A) Swarm of Anisomysis aikawai $5 \mathrm{~m}$ deep near the lower side of the brown alga Eckloniopsıs radicosa (Stn 10); (B) school of Anisomysis ijimai $4 \mathrm{~m}$ deep near a large rock (Stn 7); (C) school of Paracanthomysis hispida (indicated by arrow) $3 \mathrm{~m}$ deep among Sargassum spp. beds (Stn 6); (D) abrupt bending behavior of Lycomysis bispina when swarm $4 \mathrm{~m}$ deep was disturbed by a diver (indicated by arrow) (Stn 1 ) 
Table 3. Mysid swarms/schools observed in the present study. 'Swarms/schools partly collected; NND: nearest-neighbor dıstance

\begin{tabular}{|c|c|c|c|c|c|c|c|}
\hline Dominant species & Site & Body color & Shape & $\begin{array}{l}\text { Approximate } \\
\text { volume (1) }\end{array}$ & $\begin{array}{l}\text { Density } \\
\text { (nnd. } 1^{-1} \text { ) }\end{array}$ & $\begin{array}{l}\text { NND } \\
(\mathrm{cm})\end{array}$ & $\begin{array}{l}\text { Guest } \\
\text { species }(\%)\end{array}$ \\
\hline Anisomysis aikawai & $\begin{array}{l}\text { Near discontinuities } \\
\text { over sandy bottom }\end{array}$ & Transparent & Ball, ovoid & 0.5 to 30 & 17 to 99 & 2.1 to 3.9 & 0 to 50.0 \\
\hline A. ijimai & $\begin{array}{l}\text { Near isolated rocks } \\
\text { over sandy bottom }\end{array}$ & Transparent & Ball, ovoid & 3.0 to 2000 & 13 to 571 & 1.2 to 4.3 & 0 to 21.1 \\
\hline A. mixta & $\begin{array}{l}\text { In open water above } \\
\text { discontinuities }\end{array}$ & $\begin{array}{l}\text { Transparent, } \\
\text { brown,yellow }\end{array}$ & Ovoid & 0.5 to 2.5 & 13 to 52 & 2.7 to 4.3 & 0 to 2.3 \\
\hline A. pelewensis & Over sandy bottom & Transparent & Ball, ovoid & 0.5 to 18 & 15 to 69 & 2.4 to 4.1 & 0 to 6.2 \\
\hline Anisomysis sp. 1 & $\begin{array}{l}\text { In open water near } \\
\text { coral edge }\end{array}$ & Transparent & Ball, ovoid & $14.1,180$ & 25 & 3.4 & $0,5.4$ \\
\hline Anisomysis sp. 2 & $\begin{array}{l}\text { Near rocks over } \\
\text { gravelly bottom }\end{array}$ & $\begin{array}{l}\text { Transparent, } \\
\text { brown, yellow }\end{array}$ & Ball & 1.8 & 37 & 3.0 & 0 \\
\hline Anisomysis sp. 3 & Along seashore & Transparent & $\begin{array}{l}\text { Ovoid } \\
\text { aggregation }\end{array}$ & 2.0 & 25 & 3.4 & 10.2 \\
\hline Lycomysis bispina & $\begin{array}{l}\text { Near brown algae } \\
\text { and recesses }\end{array}$ & $\begin{array}{l}\text { Transparent, } \\
\text { yellowish-brown }\end{array}$ & Ball, ovoid & 0.4 to 7.7 & 27 to 148 & 1.3 to 3.3 & 0 to 48.0 \\
\hline Nipponomysis sp. 1 & $\begin{array}{l}\text { Near rocks and above } \\
\text { recesses over sand }\end{array}$ & Brownish & Carpet-like & $3.0,6.0$ & 24,65 & $2.5,3.4$ & $1.5,4.2$ \\
\hline Nipponomysis sp. 2 & $\begin{array}{l}\text { Near rocks over } \\
\text { sandy bottom }\end{array}$ & $\begin{array}{l}\text { Transparent, } \\
\text { white }\end{array}$ & Carpet-like & $1.6,6.3$ & 16,37 & $3.0,4.0$ & $1.0,34.2$ \\
\hline Nipponomysis sp. 3 & $\begin{array}{l}\text { Cave over sandy } \\
\text { bottom }\end{array}$ & Brown, white & Ovoid & 3.0 & 65 & 2.5 & 27.4 \\
\hline Paracanthomysis hispida & Sargassum spp beds & $\begin{array}{l}\text { Yellowish- } \\
\text { brown }\end{array}$ & Ball, ovord & 1.7 & 13 to 43 & 2.9 to 4.3 & 0 to 5.7 \\
\hline Prionomysis aspera & Over sandy bottom & Brown & Carpet-like & 1.5 & $\cdot$ & $\cdot$ & 0 \\
\hline Siriella sp. & $\begin{array}{l}\text { Near rocks over } \\
\text { sandy bottom }\end{array}$ & $\begin{array}{l}\text { Transparent, } \\
\text { brown }\end{array}$ & Column-like & 8.8 & 33 & 3.1 & 2.0 \\
\hline Tenagomysis sp. & $\begin{array}{l}\text { Above recesses over } \\
\text { sand, over sandy } \\
\text { bottom }\end{array}$ & Brown-striped & $\begin{array}{l}\text { Carpet-like, } \\
\text { huge } \\
\text { aggregation }\end{array}$ & $7.5^{* .6}$ & · & $\cdot$ & 4.7 to 6.7 \\
\hline Unidentified Leptomysini & $\begin{array}{l}\text { Over sandy bottom, } \\
\text { along seashore }\end{array}$ & $\begin{array}{l}\text { Yellowish- } \\
\text { brown, brown }\end{array}$ & Ovoid & 5.0 & 48 & 2.8 & 2.0 \\
\hline
\end{tabular}

of 2 swarms in which all constituents were juveniles were 571 and 312 ind. $1^{-1}$, much higher than those containing mixed stages ( 13 to 49 ind $\mathrm{I}^{-1}$ ).

Anisomysis mixta formed relatively small oval swarms $(10 \times 10 \times 5$ to $25 \times 20 \times 5 \mathrm{~cm})$, with densities ranging from 13 to 52 ind. $\mathrm{l}^{-1}$, above the upper side of the brown alga Eckloniopsis radicosa or large rocks (height above the bottom up to ca $1 \mathrm{~m}$ ) but not directly over sandy bottoms. A pelewensis formed exclusively oval $(40 \times 30 \times 15 \mathrm{~cm})$ or ball-shaped $(10 \mathrm{~cm})$ active schools over sandy bottoms at densities similar to those of $A$. mixta. The schools moved at distances of 5 to $100 \mathrm{~cm}$ above the bottom. The other 3 species of Anisomysis formed swarms or schools peculiar to each species. Anisomysis sp. 1 was observed forming large oval $(30 \times 30 \times 200 \mathrm{~cm})$ and small ball-shaped $(30 \mathrm{~cm})$ swarms 30 to $40 \mathrm{~cm}$ away from the edges of living corals in open water. In Anisomysis sp. 2 a spherical school (diam. $15 \mathrm{~cm}$ ) was found near a rock over gravelly bottom, whereas in Anisomysis sp. 3 a loose aggregation containing a lot of oval swarms was formed along the wave zone at a depth of less than $1 \mathrm{~m}$.

Lycomysis bispina, Nipponomysis sp. 3, and Paracanthomysis hispida also formed oval or ball-shaped swarms/schools, but their formation sites and polarization differed. L. bispina (Fig. 5D) formed swarms/ schools near rocks over the sandy bottoms or in the spaces surrounded by the brown algae Undaria pinnatifida, Sargassum spp. and the red alga Grateloupia filicina, with density ranging from 27 to 148 ind. $\mathrm{l}^{-1}$. A swarm of Nipponomysis sp. 3 was found beneath a notch of a large rock over the sandy bottom. Paracanthomysis hispida (Fig. 5C) formed active, highly integrated schools only within Sargassum spp. beds. The 
body color of $P$. hispida is yellowish brown, which is similar to that of Sargassum spp. fronds and bladders and may function as mimicry against fish predation.

Aggregations of Anisomysis sp. 3 were distributed along the wave zone, their sizes ranging from a few $m$ to around $10 \mathrm{~m}$ in length. The aggregations contained a number of small swarms and schools and constantly changed form in accordance with the subgroups (swarms/schools). In Tenagomysis sp., a huge aggregation (about $10 \mathrm{~m}$ in length and width) covered the sandy bottom at a depth of $3 \mathrm{~m}$ and was formed within a distance of ca $50 \mathrm{~cm}$ from the substrate. The aggregation involved small migratory schools. Estimated NNDs ranged from 1.2 to $4.4 \mathrm{~cm}$ and were nearly constant irrespective of species.

\section{Stage composition and sex ratio}

The developmental stage composition and sex ratios within swarms are shown in Table 4. Almost all swarms were composed of individuals of various developmental stages, juveniles and immature and mature females/males. However, in Anisomysis aikawai and $A$. ijimai, swarms were observed in which all the constituents were juveniles. In contrast, actively migrating schools of A. ijimai, A. pelewensis, Anisomysis sp. 2, and Paracanthomysis hispida tended to consist mainly of advanced developmental stages, with juveniles occupying less than 36\% (Fig. 3). All swarms of Lycomysis bispina contained all categories in a wide variety of ratios

All swarms contained both sexes, with sex ratios $(0 / \%)$ ranging from 0.22 to 2.40 .

\section{DISCUSSION}

\section{Characteristics of groups}

Species composition

A number of shallow-water mysids have hitherto been directly observed forming a variety of groups (Table 5). All of those species, except for Anchialina agilis (the subfamily Gastrosaccinae) and Siriella jaltensis (the subfamily Siriellinae), belong to the subfamily Mysinae. Previous reports of gregarious behavior in the Gastrosaccinae and Siriellinae have been few. Wittmann (1977) reported that $S$. jaltensis, $S$. armata and $A$. agilis exhibited only solitary behavior and clung to leaves of Zostera during the day and that $S$. jaltensis and $A$. agilis joined swarms only as guest species. Some species of Gastrosaccus (Gastrosaccinae) are known to burrow into sand during the day (Mauchline 1980). In the present study, Siriella sp. was observed forming an almost monospecific stationary school (Table 3 ). The present and previous studies revealed that the genera Acanthomysis, Anisomysis, Leptomysis, Mysidium, Neomysis, Nipponomysis and Tenagomysis commonly form groups in shallow waters. The genera Prionomysis and Paracanthomysis were first found to form groups in this study.

Although O'Brien (1988b) mentioned that mysid swarms/schools are basically monospecific, the present study revealed that the combination of 1 dominant species with 1 or more guest species in a group commonly occurs in the temperate and subtropical regions of Japan and Korea (Fig. 2). Wittmann (1977) and Morioka \& Kimoto (1986) also reported poly-

Table 4. Stage composition and sex ratio of mysid groups observed in the present study. Sex ratio calculated from the numbers of matures and immatures. "Only part of group collected (the number of "represents the number of partially collected groups)

\begin{tabular}{|c|c|c|c|c|c|c|c|}
\hline \multirow[t]{2}{*}{ Dominant species } & \multirow{2}{*}{$\begin{array}{l}\text { No. of } \\
\text { samples }\end{array}$} & \multicolumn{5}{|c|}{ Percentage of mature individuals (\%) } & \multirow{2}{*}{$\begin{array}{c}\text { Sex ratio } \\
\left(0^{*} / 9\right)\end{array}$} \\
\hline & & 0 & $0-25$ & $25-50$ & $50-75$ & $75-100$ & \\
\hline Anisomysis aikawai & 6 & 2 & 3 & 0 & 0 & $1^{*}$ & $0.32-1.20$ \\
\hline A. ijimai & 9 & 2 & $5 \cdots$ & 1 & 0 & 1 & $0.62-2.40$ \\
\hline A. mixta & 6 & 0 & 2 & 2 & 2 & 0 & $0.33-2.39$ \\
\hline A. pelewensis & 9 & 0 & 1 & 1 & 4 & 3 & $0.47-2.14$ \\
\hline Anisomysis sp. 1 & 2 & 0 & 0 & 1 & $1^{\cdot}$ & 0 & 1.09 \\
\hline Anisomysis sp. 2 & 1 & 0 & 0 & 1 & 0 & 0 & 0.91 \\
\hline Anisomysis sp. 3 & 1 & 0 & 0 & 0 & 1 & 0 & 0.26 \\
\hline Lycomysis bispind & 28 & 0 & 12 & 10 & 6 & 0 & $0.22-1.31$ \\
\hline Nipponomysis sp. 1 & 2 & 0 & 0 & 2 & 0 & 0 & $0.34-1.02$ \\
\hline Nipponomysis sp. 2 & 2 & 0 & 2 & 0 & 0 & 0 & $0.81-0.94$ \\
\hline Nipponomysis sp. 3 & 1 & 0 & 1 & 0 & 0 & 0 & 0.39 \\
\hline Paracanthomysis hispida & 5 & 0 & 1 & 2 & 1 & $1{ }^{\circ}$ & $0.40-2.14$ \\
\hline Prionomysis aspera & 1 & 0 & 0 & 0 & $1^{\cdot}$ & 0 & 1.50 \\
\hline Siriella sp. & 1 & 0 & 0 & 0 & 0 & 1 & 1.29 \\
\hline Tenagomysis sp. & 2 & 0 & 0 & $1^{\cdot}$ & 0 & $1^{*}$ & $0.33-0.61$ \\
\hline Unidentified Leptomysini & 1 & 0 & 1 & 0 & 0 & 0 & 1.49 \\
\hline
\end{tabular}


Table 5. Mysid swarms/schools/aggregations examined in previous direct field observations

\begin{tabular}{|c|c|c|}
\hline Species & Shape, size, site and other characteristics & Source \\
\hline Acanthomysis sp. A & $\begin{array}{l}\text { Huge aggregation of a few to tens of meters across; spherical/flattened; } \\
\text { above sandy or rocky bottoms; } 3 \text { to } 10 \mathrm{~m} \text { depth; polarized/unpolarized; } \\
\text { height above substrate } 0 \text { to } 30 \mathrm{~cm} \text { up to } 1.5 \mathrm{~m}\end{array}$ & Clutter (1969) \\
\hline Acanthomysis sp. B & $\begin{array}{l}\text { Huge aggregation of a few to tens of meters across; above sandy bottoms; } \\
13 \text { to } 21 \mathrm{~m} \text { depth; unpolarized; height above substrate } 70 \mathrm{~cm}\end{array}$ & Clutter (1969) \\
\hline Acanthomysis sp. & At biogenic structures; unpolarized & Wittmann (1977) \\
\hline Acanthomysis sp. & In shadowed places along the bank in mangrove swamps; polarized & Omori \& Hamner (1982) \\
\hline Anchialina agilis & Only as guest species & Wittmann (1977) \\
\hline Anisomysis mixta-australis & $\begin{array}{l}\text { Ovoid/variable dependent on substrates; } 0.3 \times 0.2 \times 0.2 \text { to } 4 \times 2 \times 0.5 \mathrm{~m} \text {; } \\
\text { associated with discontinuities usually over sandy bottom; } \\
1 \text { to }>10 \mathrm{~m} \text { depth; polarized; height above substrate } 10 \mathrm{~cm} \text { to } 1.5 \mathrm{~m}\end{array}$ & O'Brien (1988b) \\
\hline Australerythrops paradicei & $\begin{array}{l}\text { Ovoid; } 1 \times 1 \times 0.5 \text { to } 4 \times 2 \times 2 \mathrm{~m} \text {; caves; } 8 \text { to } 15 \mathrm{~m} \text { depth; polarized; } \\
\text { height above substrate } 30 \mathrm{~cm} \text { to } 2 \mathrm{~m}\end{array}$ & O'Brien (1988b) \\
\hline Doxomysis $\mathrm{sp}$. & $\begin{array}{l}\text { Dictated by substrate relief; } 0.2 \times 0.0 \times 0.05 \text { to } 1 \times 1 \times 0.2 \mathrm{~m} \text {; associated with } \\
\text { depressions/furrows in rocks or gaps between algae; } 2 \text { to }>30 \mathrm{~m} \text { depth; } \\
\text { polarized by current; height above substrate } 0 \text { to } 30 \mathrm{~cm}\end{array}$ & O'Brien (1988b) \\
\hline Leptomysis apiops & $\begin{array}{l}\text { At biogenic structures; } 18 \text { to } 34 \mathrm{~m} \text { depth; unpolarized; height above } \\
\text { substrate up to } 8 \mathrm{~cm}\end{array}$ & Wittmann (1977) \\
\hline L. lingvura & $\begin{array}{l}\text { Spherical; } 20 \mathrm{~cm} \text { in diameter; Anemonia sulcata/rocks/recesses of rocks; } \\
0.5 \text { to } 6 \mathrm{~m} \text { depth; exhibiting homing behavior; height above substrate up } \\
\text { to } 30 \mathrm{~cm}\end{array}$ & Wittmann (1977) \\
\hline L. mediterraned & $\begin{array}{l}\text { Over sandy bottoms; } 1 \text { to } 8 \mathrm{~m} \text { depth; polarized/unpolarized; height above } \\
\text { substrate up to } 50 \mathrm{~cm}\end{array}$ & Wittmann (1977) \\
\hline L. sardica & $\begin{array}{l}\text { Loose aggregations of } 2 \text { to } 8 \text { specimens in Zostera beds in summer/swarms } \\
\text { or schools over sandy bottoms in February; } 1 \text { to } 12 \mathrm{~m} \text { depth; polarized/ } \\
\text { unpolarized; height above substrate changing from } 3 \mathrm{~cm} \text { to } 50 \mathrm{~cm}\end{array}$ & Wittmann $(1977)$ \\
\hline Leptomysis sp. A & $\begin{array}{l}\text { Anemonia sulcata/rocks/algae; } 4 \text { to } 12 \mathrm{~m} \text { depth; unpolarzied; height above } \\
\text { substrate up to } 30 \mathrm{~cm}\end{array}$ & Wittmann $(1977)$ \\
\hline Leptomysis sp. B & $\begin{array}{l}\text { Rocks/algae; } 14 \text { to } 30 \mathrm{~m} \text { depth; unpolarized; height above substrate } \\
\text { up to } 30 \mathrm{~cm}\end{array}$ & Wittmann $(1977\}$ \\
\hline Lycomysis bispina & $\begin{array}{l}\text { Ovoid; } 30 \text { to } 50 \mathrm{~cm} \text { in diameter and } 1 \text { to } 2 \mathrm{~m} \text { in length; lee side of rocks/ } \\
\text { gaps between brown algae and Zostera marina; } 5 \mathrm{~m} \text { depth; polarized }\end{array}$ & $\begin{array}{l}\text { Morioka \& Kimoto } \\
\text { (1986) }\end{array}$ \\
\hline Metamysidopsis elongata & $\begin{array}{l}\text { Above fine sand; } 3 \text { to } 15 \mathrm{~m} \text { depth; polarized/unpolarized; } \\
\text { height above substrate } 5 \mathrm{~cm} \text { to } 1 \mathrm{~m}\end{array}$ & Clutter (1969) \\
\hline Mysidium columbiae & $\begin{array}{l}\text { In shoals close to mangroves/inside caves/along coral faces; } \\
<1 \text { to } 30 \mathrm{~m} \text { depth/a few } \mathrm{cms} \text { below the sea surface }\end{array}$ & $\begin{array}{l}\text { Steven (1961), Emery } \\
\text { (1968) }\end{array}$ \\
\hline M. gracile & $\begin{array}{l}\text { Inside caves/along coral faces; associated with nest of pomacentrid fish } \\
\text { or sea urchin Diadema antillarum; less than } 1 \text { to } 4 \mathrm{~m} \text { depth }\end{array}$ & $\begin{array}{l}\text { Randall et al. (1964), } \\
\text { Emery (1968) }\end{array}$ \\
\hline M. integrum & Inside caves/along coral faces; less than 1 to $30 \mathrm{~m}$ depth & Emery (1968) \\
\hline Mysidopsis sp. & Sand channels among rocks/open sand flat; 3 to $15 \mathrm{~m}$ depth & Clutter (1969) \\
\hline Mesopodopsis slabberi & $\begin{array}{l}\text { No visible substrate preferences; schools sometimes migrating with } \\
\text { stopping at discontinuities; polarized; height above substrate up to } 50 \mathrm{~cm}\end{array}$ & Wittmann (1977) \\
\hline Neomysis integer & Swarms/aggregations; at the mouth of rivers or streams; 1 to $5 \mathrm{~m}$ depth & Mauchline (1971) \\
\hline N. japonica & $\begin{array}{l}\text { Some tens of meters; near bottom in the lagoon along the waterway; } \\
\text { polarized }\end{array}$ & Omori \& Hamner (1982) \\
\hline N. mirabilis & $\begin{array}{l}\text { Ribbon-shaped/spherical/spindle-shaped; } 2 \text { to } 3 \mathrm{~m} \text { long; Zostera } \\
\text { beds/water edge; } 0.5 \text { to } 3 \mathrm{~m} \text { depth; some dozens to several thousands } \\
\text { in a swarm; sometimes polarized }\end{array}$ & Zelickman (1974) \\
\hline Neomysis sp. & At biogenic structures; unpolarized i height above substrate up to $8 \mathrm{~cm}$ & Wittmann (1977) \\
\hline Nipponomysis fusca & $\begin{array}{l}\text { Spherical; ca } 30 \mathrm{~cm} \text { in diameter; lee side of artificial fish reefs/cave, } \\
28 \text { to } 36 \mathrm{~m} \text { depth }\end{array}$ & Kakimoto et al. (1983) \\
\hline Paramesopodopsis rufa & $\begin{array}{l}\text { Cigar-shaped/discoid/ovoid; } 100 \mathrm{~cm}^{3} \text { to } 3 \times 3 \times 1 \mathrm{~m} \text {; prefers algal- } \\
\text { covered rock outcrops; } 1 \text { to }>20 \mathrm{~m}^{\text {depth; }} \text { unpolarized; height } \\
\text { above substrate } 10 \mathrm{~cm} \text { to } 2 \mathrm{~m}\end{array}$ & O'Brien (1988b) \\
\hline Praunus flexuosus & Aggregations; over sand; 1 to $5 \mathrm{~m}$ depth & Mauchline (1971) \\
\hline$P$. inermis & Aggregations; over sand; 1 to $5 \mathrm{~m}$ depth & Mauchline (1971) \\
\hline P. neglectus & $\begin{array}{l}\text { Aggregations; among weeds/sandy areas of a few meters width } \\
\text { surrounded by seaweeds; } 1 \text { to } 5 \mathrm{~m} \text { depth }\end{array}$ & Mauchline (1971) \\
\hline Schistomysis kervillei & Swarm/aggregation in sandy bays; 1 to $5 \mathrm{~m}$ depth & Mauchline (1971) \\
\hline S. spiritus & $\begin{array}{l}\text { Swarm/aggregation in sandy bays sheltered from strong waves; } \\
1 \text { to } 5 \mathrm{~m} \text { depth }\end{array}$ & Mauchline (1971) \\
\hline Sinella jaltensis & Only as guest species & Wittmann (1977) \\
\hline Tasmanomysis oculata & $\begin{array}{l}\text { Discoid with flat vertical axes; } 1 \times 1 \times 0.25 \text { to } 4 \times 4 \times 0.25 \mathrm{~m} \text {; near } \\
\text { discontinuities/in surf zone; } 0.5 \text { to } 3 \mathrm{~m} \text { depth; polarized; height } \\
\text { above substrate } 30 \mathrm{~cm} \text { to } 1 \mathrm{~m}\end{array}$ & O'Brien (1988b) \\
\hline Tenagomysis sp. & $\begin{array}{l}\text { Compressed along vertical axes; } 0.5 \times 0.5 \times 0.05 \text { to } 30 \times 2 \times 0.2 \mathrm{~m} \text {; associated } \\
\text { with sand; } 1 \text { to } 15 \mathrm{~m} \text { depth; polarized; height above substrate } 0 \text { to } 50 \mathrm{~cm}\end{array}$ & O'Brien (1988b) \\
\hline
\end{tabular}


specific groups in the Adriatic Sea and western Japan, respectively. In the present study, congeners with similarities in size, body color or social behavior tend to group together preferentially. For example, migratory schools of Anisomysis pelewensis often contained congeneric guest species, A. aikawai and A. mixta, whose swarms were normally stationary (Table 2). Wittman (1977) suggested that polyspecific swarms are caused by 2 factors, preference for the same habitat and nonspecific gregariousness. The stationary groups of A. aikawai and Lycomysis bispina which were found containing many guest species in the present study may have been a result of the former preference. The $A$. pelewensis- $A$, aikawai and $A$. pelewensis- $A$. mixta associations probably correspond to the latter preference. In A. aikawai and L. bispina, 2 or more swarms/schools might have been mixed together because of their preference for the same habitat.

\section{Substrate preference}

Wittmann (1977) clearly demonstrated that there is a broad spectrum of mysid behavior, ranging from 'substrate-specialists' to 'swarm-specialists', which shows additional differences in body color and antipredatory behavior. Although the present study dealt only with swarm-specialists, body color, activity, substratepreference and height above substrate varied greatly for the species observed. Nipponomysis sp. 1, Prionomysis aspera and Tenagomysis sp., which all formed flat swarms just above sandy bottoms, were entirely or partly brownish in body color, suggesting these species adopt both camouflage and swarming strategies (see Wittmann 1977) for antipredation. In the elliptical and ball-shaped swarms/schools of Anisomysis spp., Lycomysis bispina and Paracanthomysis hispida the integrity between constituents seemed to be more intensified and independent of substrate than that in the flat swarms in that they formed 3 dimensional groups and, in some cases, highly integrated migratory ones

Groups of mysids are commmonly found over a wide variety of substrates: over sandy, gravelly and rocky bottoms, among seaweeds, in caves, in recesses and discontinuities, near corals, and with other benthic invertebrates or demersal fishes (Table 5). Each species has its own preferred substrate type, even the migratory types of mysids. In shallow waters various species are segregated by bathymetric zones and substrates (Clutter 1967, Wittmann 1977, O'Brien 1988b).

The closest relationship between grouping behavior and substrate preference is found in species com- mensal with other invertebrates (Table XXXI in Mauchline 1980). Such relationships were never found in the present study. On the other hand, the relationships we found are not necessarily consistent for some species. In Tenagomysis sp., the type and site of grouping changed seasonally. In Anisomysis ijimai the mobility of the swarms converted from stationary type to migratory type with maturity. Wittmann (1977) also reported seasonal change in social behavior of Leptomysis sardica from loose aggregations in Zostera beds in summer to stationary schools over the sandy bottom in February

\section{Polarization}

Polarization of individuals can change with space and time in some species. For Lycomysis bispina, we found both unpolarized swarms and stationary schools at depths of 4 to $6 \mathrm{~m}$ in the Seto Inland Sea throughout the year, but Morioka \& Kimoto (1986) observed a school migrating slowly among seaweeds and rocks at a depth of $5 \mathrm{~m}$ in the western Kyushu in August. Other species also form both unpolarized swarms and polarized schools (Table 5). In Anisomysis mixta-australis, swarming was observed only in stagnant waters in the laboratory, whereas polarized schooling was exclusively found in the field (O'Brien 1988b). This suggests that current is an important factor causing polarization in this species.

\section{Density}

Numerical density in the mysid swarms/schools in the present study ranged from 13 to 571 ind. $\mathrm{I}^{-1}$. Densities in schools were up to 2.5 ind. $^{-1}$ in Neomysis japonica (Omori \& Hamner 1982), 14 in Lycomysis bispina (Morioka \& Kimoto 1986), and 50 to 700 in Acanthomysis sp. A (Clutter 1969). The maximum density recorded in the present study was in a swarm of Anisomysis ijimai composed only of juveniles. In $A$. aikawai and $A$. ijimai swarms of a higher density were dominated by juveniles. Instead of density, NNDs have been used to express degree of aggregation in many mysids, probably partly because of relatively irregular shapes of mysid swarms and partly because their high net avoidance ability $\left(>20 \mathrm{~cm} \mathrm{~s}^{-1}\right.$ escape speed; O'Brien \& Ritz 1988) makes exact quantitative sampling difficult. Although the estimated NNDs in the present study were calculated from. densities found, the values are very similar to those found in other studies for other group-forming mysids (1 to $4 \mathrm{~cm}$ or 0.7 to 6.5 body lengths; see Table IX in O'Brien 1989). 


\section{Stage composition}

The stage composition in mysid groups was temporally and spatially variable in the present and previous studies. For example, although all swarms/schools of Lycomysis bispina consisted of juveniles and immature and mature females and males throughout the year stage composition fluctuated seasonally, with juveniles comprising 2 to $73 \%$ and mature adults 3 to $60 \%$ of the total number (Inagaki 1990). Swarms of Anisomysis aikawai and A. ijimai also contained a variety of developmental stages, although some swarms were made up exclusively of juveniles. A. mixta-australis and Metamysidopsis elongata also formed groups composed only of juveniles (Clutter 1969, O'Brien 1988b). The facts suggest that these mysids have no solitary phase in their life history. No observations have ever been made on mysid groups containing only a single sex. Clutter (1969) and O'Brien (1988b) mentioned that all swarms of $A$. mixta-australis, Australerythrops paradicei, M. elongata, Paramesopodopsis rufa, Tasmanomysis oculata, and Tenagomysis sp. were generally composed of individuals at similar stages of maturity. Similar tendencies were found in $A$. mixta, $A$. pelewensis and $P$. hispida (Fig 3, Table 4).

\section{Sex ratio}

Sex ratio in mysid populations is known to vary among samples and among seasons, usually in favor of females (Mauchline 1980). This is also true in the present study. For example the sex ratio of Lycomysis bispina in 28 swarms ranged from 0.2 to 1.3 (0.89 on average), which falls within those of the previous reports in other species (0.2 to 0.9; Mauchline 1980). No extreme imbalance (up to 1:19 or 1:59) in the ratio (Mauchline 1980) has been observed.

\section{Possible adaptive values of mysid grouping behavior}

Present and previous studies on mysid swarms suggest that antipredation and position maintenance are the most important adaptive advantages for gregariousness. For example, groups of Idiomysis spp. associated with sea anemones and medusae (Bacescu 1973), swarms/schools of Mysidium gracile associated with the sea urchin Diadema antillarum (Randall et al. 1964 Emery 1968, Hahn \& Itzkowitz 1986), nesting pomacentrid fishes (Emery 1968) and damselfish territories (Hahn \& Itzkowitz 1986) are also thought to be highly adapted to antipredation. Actively migrating schools of brown-colored Paracanthomysis hispida associated with Sargassum spp. beds can fade into the back- ground to escape from visual predators. Swarms of Anisomysis aikawai, A. ijimai (present study) and $A$. mixta-australis (O'Brien 1988b) which consisted exclusively of juveniles seemed to have no connection with reproductive behavior and most likely occurred for antipredation. Although some swarms/schools of mysids were observed to be broken up and fed upon by fishes (Emery 1968, for Mysidium columbiae; Hahn \& Itzkowitz 1986, for $M$. integrum; present study, for $A$. ijimai), mysids' overall gregarious behaviors apparently favor antipredation.

Some mysids also aggregate for feeding (cf. Omori \& Hamner 1982). In surf zones of sandy beaches, where accumulation of some zoo- and phytoplankters trapped by wind or tidal action may occur, some mysids were observed feeding voraciously on a pelagic harpacticoid copepod, Microsetella norvegica (Ito 1985), and Gastrosaccus psammodytes was associated with diatom accumulations (Wooldridge 1989). Swarms of Anisomysis sp. 3 (present study) and Tenagomysis sp. (O'Brien 1988b) (Table 3) found aggregating along such zones are also considered as those for feeding

Mauchline (1971) and O'Brien (1988b) reported that some mysid species make swarms for reproduction because they found swarms consisting predominantly of mature adult individuals. However, shallow-water mysids generally copulate at night when they disperse throughout the water column or morphologies of groups greatly change (Murano 1964, Clutter 1969, Mauchline 1980, Wittmann 1981, Inagaki 1990).

The present study evidently revealed that mysids form polyspecific groups almost consistently composed of a dominant species in association with 1 or more guest species on Japanese and Korean coasts. The formation of polyspecific groups in the family Mysidae has been hitherto recorded in other regions (Wittman 1977, O'Brien 1988b). Polyspecific gregariousness is probably common in group-forming species of the family. Group cohesion appears to be more important in the mysid community than was surmised in previous studies and the following 2 adaptive advantages are assumed: (1) stray mysids temporarily join groups of dominant species as guests for antipredation and (2) connection of some small subgroups into 1 large group is more effective for antipredation and position maintenance.

Acknowledgements. We are grateful to Drs J. G. Greenwood (University of Queensland) and D. A. Ritz (University of Tasmania) for their critical reading of the manuscript. We also express our sincere thanks to Prof. M. Murano (Tokyo University of Fisheries) for identification of Anisomysis spp. and to the captain and crew of TRV 'Toyoshio-maru' (Hiroshima University), Drs Y. D. Lee and Y. K. Kim (Cheju National University), and Mr. M. Ohtsuka (Hiroshima University) for cooperation at sea. This study was supported in part by a grant from the Research Institute of Marine Invertebrates awarded to S.O. 


\section{NOTE ADDED IN PROOF}

Anisomysis sp. 2 examined in the present study was described as A. ohtsukaj by Murano (1994)

\section{LITERATURE CITED}

Bacescu M (1973) A new case of commensalism in the Red Sea: the mysid Idiomysis tsurnamali $\mathrm{n}$. sp. with the coelenterata Megalactis and Cassiopea. Rev Roum Biol, Ser Zool 18:3-7

Clutter RI (1.967) Zonation of nearshore mysids. Ecology 48: $200-208$

Clutter RI (1969) The microdistribution and social behavior of some pelagic mysid shrimps. $J$ exp mar Biol Ecol 3: $125-155$

Emery AR (1968) Preliminary observations on coral reef plankton. Limnol Oceanogr 13:293-303

Hahn P, Itzkowitz M (1986) Site preference and homing behavior in the mysid shrimp Mysidium gracile (Dana). Crustaceana 51:215-219

Hamner WM, Carleton JH (1979) Copepod swarms: attributes and role in coral reef ecosystems. Limnol Oceanogr 24 $1-14$

Imabayashi $\mathrm{H}$ (1980) Feeding activities of juveniles and young bastard halibut, Paralinchthys olivaceus, in the biotic community. I. Intraspecific relationships in the population. Bull Jap Soc scient Fish 46:427-235

Inagaki H (1990) A study on the behavioral ecology of mysids MSc thesis, Hiroshima University (in Japanese)

Ito $\mathrm{T}$ (1985) Organisms in sand interstices. Kalmei-sha, Tokyo (in Japanese)

Kakimoto $\mathrm{H}$, Ohkubo $\mathrm{H}$, Itano $\mathrm{H}$, Arai K (1983) Distribution of zooplankton near artificial fish reefs. Fish Eng 19:21-28 (in Japanese)

Kimoto K, Nakashima J, Morioka Y (1988) Direct observations of copepod swarm in a small inlet of Kyushu, Japan. Bull Seikai reg Fish Res Lab 66:41-58

Kiso K (1980) On the feeding habit of 0-group red sea bream Pagrus major in Shijiki Bay, Hirado Island. 1. Sequential changes of the diets with growth and its annual variation Bull Seikai reg Fish Res Lab 54:291-306

Kiso $\mathrm{K}$ (1981) On the feeding habit of 0-group crimson sea bream, Evynnis japonica, in Shijiki Bay, Hirado Island. Bull Seikai reg Fish Res Lab 56:15-25

Mauchline J (1971) Seasonal occurrence of mysid (Crustacea) and evidence of social behaviour. $J$ mar biol Ass UK 51 $809-825$

Mauchline J (1980) The biology of mysids. Adv mar Biol 18: $1-369$

Morioka Y, Kimoto K (1986) Opossum shrimp school from a dip of SCUBA sweeping in a small inlet. Bull Sekai reg Fish Res Lab 63:61-71

Murano M (1964) Fisheries biological study on Neomysis intermedia Czerniawsky. Aquaculture 12:109-117 (in Japanese)

Murano M (1994) Anisomysis (Paranisomysis) ohtsukai (Crustacea, Mysidacea), a new mysid from Japan. Bull Natl Sci Mus, Tokyo, Ser A 20(4):155-159
O'Brien DP (1988a) Surface schooling behaviour of the coastal krill Nyctiphanes australis (Crustacea: Euphausiacea) off Tasmania, Australia. Mar Ecol Prog Ser 42:219-233

O'Brien DP (1988b) Direct observations of clustering (schooling and swarming) behavior in mysids (Crustacea: Mysidacea). Mar Ecol Prog Ser 42:235-246

O'Brien DP (1989) Analysis of the internal arrangement of individuals within crustacean aggregations (Euphausiacea, Mysidacea). J exp mar Biol Ecol 128:1-30

O'Brien DP, Ritz DA (1988) Escape responses of gregarious mysids (Crustacea: Mysidacea): towards a general classification of escape responses in aggregated crustaceans $\mathrm{J}$ exp mar Biol Ecol 116:257-272

O'Brien DP, Tay D, Zwart P (1986) Laboratory method of analysis of swarming behavior in macroplankton: combination of a modified flume tank and stereophotographic technique. Mar Biol 90:517-527

Omori M, Hamner WM (1982) Patchy distribution of zooplankton: behavior, population assessment and sampling problems. Mar Biol 72:193-200

Partridge BL (1980) The effect of school size on the structure and dynamics of minnow schools. Anim Behav 28:68-77

Randall JE, Schroeder RE, Strack WA II (1964) Notes on the biology of the echinoid Diadema antillarum. Caribb J Sci $4: 421-433$

Steven DM (1961) Shoaling behaviour in a mysid. Nature 192: $280-281$

Tanaka M, Ueda $H$, Azeta M (1987a) Near-bottom copepod aggregations around the nursery ground of the juvenile red sea bream in Shijiki Bay. Nippon Suisan Gakkaishi $53: 1537-1544$

Tanaka M, Ueda H, Azeta M, Sudo H (1987b) Significance of near-bottom copepod aggregations as food resources for the juvenile red sea bream in Shijiki Bay. Nippon Suisan Gakkaishi 53:1545-1552

Tanimura A, Minoda T, Fukuchi M, Hoshiai T, Ohtsuka H (1984) Swarm of Paralabidocera antarctica (Calanoida, Copepoda) under sea ice near Syowa Station, Antarctica. Antarctic Rec 82:12-19

Toda H, Takahashi M (1982) An application of sucroseformalin preservation technique to Mysidacea. Bull Plankton Soc Japan 29:129-130

Ueda $H_{1}$ Kuwahara A, Tanaka M, Azeta M (1983) Underwater observations on copepod swarms in temperate and subtropical waters. Mar Ecol Prog Ser 11:165-171

Wittmann KJ (1977) Modification of association and swarming in North Adriatic Mysidacea in relation to habitat and interacting species. In: Keegan BF, $\mathrm{O}^{\prime}$ Ceidigh $P$, Boaden PJS (eds) Biology of benthic organisms. Pergamon Press, Oxford, p 605-612

Wittmann KJ (1981) Comparative biology and morphology of marsupial development in Leptomysis and other Mediterranean Mysidacea (Crustacea). J exp mar Biol Ecol 52: $243-270$

Wooldridge TH (1989) The spatial and temporal distribution of mysid shrimps and phytoplankton accumulations in a high energy surfzone. Vie Milieu 39:127-133

Zelickman EA (1974) Group orientation in Neomysis mirabilks (Mysidacea: Crustacea). Mar Biol 24:251-258

Manuscript first received: August 8, 1994

Revised version accepted: February 15, 1995 